\title{
Drought Tip
}

\section{Drought Tips for Vegetable Production}

\section{D}

roughts are a frequent phenomenon of the Californian climate, recurring every 5 to 15 years and lasting for 1 to 4 years. Because most of the developed water in California is needed for growing crops, droughts have far-reaching consequences for the agricultural industry. As the state population continues to grow and more water is needed for sustaining wildlife habitat, less irrigation water may be available for farmers than in the past.

Contingency for drought should be part of every grower's business plan in California. This publication outlines a range of strategies to consider for growing vegetables under a limited water supply.

\section{Evaluate Options for Maximizing Production and Profitability}

When water supplies are limited during a drought, options to maximize production and profitability need to be considered. Producing crops that are most profitable per unit of applied water is an important consideration, as well as growing crops during periods when prices are higher than normal.

Because yield and quality of vegetable crops usually decline when underirrigated, it is often better to reduce the acres planted than to spread a limited water supply over too large of an area. For some warm season vegetables such as tomatoes and some melons, water stress may increase brix and other flavor qualities if timed during fruit maturation and ripening, but yield may also decline. UC ANR Drought Tip 8632 covers how to estimate vegetable crop water needs and the acres that can be irrigated when water supplies are limited (Cahn 2019).

If it is necessary to reduce planted acreage due to a limited water supply, then consider planting on the most productive land. This should be land with soils most suited for vegetable production, such as uniform, deep soils or land in the best climatic zone. Avoid land with soils that have high salinity, impermeable and compacted layers, or excessive slope. 
Also, avoid cropping land with a history of soil-borne diseases that may affect production or land adjacent to areas that may harbor insect pests that may adversely affect vegetables.

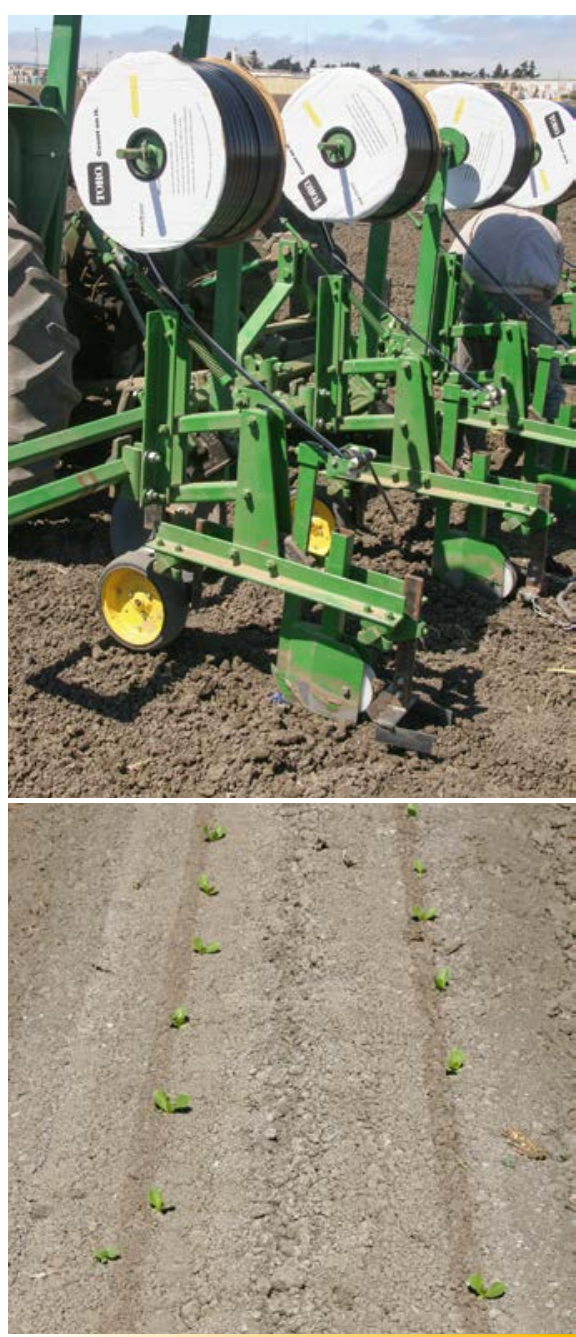

Figure 1. Drip tape applicator (top) can inject tape at a consistent depth so that lettuce (bottom) can be germinated using drip irrigation. Photo: M. Cahn.
Profitability under a limited water supply can be enhanced by following good fertility and pest management practices. A sufficient supply of nutrients will help plants develop an extensive root system and potentially improve the efficiency of the crop to utilize soil moisture. Test soil for macro- and micronutrients at the beginning of the season, and add amendments and fertilizers needed for maximizing crop production. Insect and disease pests that stunt crop development or reduce quality also will harm productivity.

Choosing varieties that are best suited for a region and specific time of year is a basic strategy that can also improve water use efficiency of vegetables. Seek advice from seed companies and consultants familiar with the varieties grown in the production region of interest. Droughttolerant or short-season varieties should also be considered if they produce more marketable yield per unit of applied water than conventional varieties. Varieties that tend to have deep root systems may tolerate water stress better than shallower-rooted varieties. Also using varieties with pest resistance and desirable quality traits will help assure that marketable yield is maximized.

\section{Increase Irrigation Efficiency}

Another way to improve profitability under a limited water supply is to use irrigation water efficiently so that more acres can be cultivated. This strategy may begin with minimizing preseason and crop establishment water, but also includes increasing application efficiency, good irrigation scheduling, applying an appropriate leaching fraction, and limiting evaporative losses.

Minimize Water Applied Preseason and for Stand Establishment Establishing a vegetable crop with a uniform plant size and population is critical for maximizing yield and quality. Preseason water is often used to leach accumulated salts and establish uniform moisture in the soil. Water applied for this purpose can often be reduced by evaluating preexisting soil moisture. Measuring the salinity of the soil can also help determine if extra irrigation is required for leaching. After the first irrigation for stand establishment, the amount of water applied for subsequent irrigations should be appropriate to maintain uniform moisture in the field. Since the soil is usually saturated after the first water, irrigating too long during subsequent irrigations may cause runoff or deep percolation losses. Because most of the water losses are due to evaporation from the soil surface, the amount of water needed will be closely related to the reference evapotranspiration (ET). Irrigating more frequently, but for short periods, may better match applied water with ET during the establishment phase of the crop than applying water less frequently but for long periods. Frequently checking soil moisture at the depth of transplant roots or seed can provide guidance on the amount of water and timing of irrigations.

Switching from seed to using transplants may also reduce water needed for stand establishment and reduce overall water use by shortening the crop cycle. Using drip irrigation can reduce water needed for germination and transplant establishment by minimizing evaporation losses from the furrow and better matching the application amount and interval with crop ET. Drip establishment of vegetables requires a soil texture that can move moisture laterally to the seed or transplant row and equipment for accurately placing the drip line at a sufficient distance and depth from the seed or transplant row to provide uniform moisture (fig. 1).

Improve the Distribution Uniformity of an Irrigation System Increasing application efficiency by maximizing the distribution uniformity (DU) of an irrigation system can reduce water 
use. For example, improving the distribution uniformity of a sprinkler system from 50 to 80 percent could reduce the irrigation requirement by 7.5 inches of water ( $38 \%$ reduction) if the crop ET requirement is 10 inches:

Water requirement for a DU of $50 \%$ :
10 inches $\times 100 \% / 50 \%=20$ inches

Water requirement for a DU of $80 \%$ :

10 inches $\times 100 \% / 80 \%=12.5$ inches

Periodically evaluating the DU can determine if the application uniformity of an irrigation system can be improved (fig. 2). Improvements in system design, operation, or maintenance may be able to increase the DU of an irrigation system. For example, poor pressure management or leaks (fig. 3) can limit the

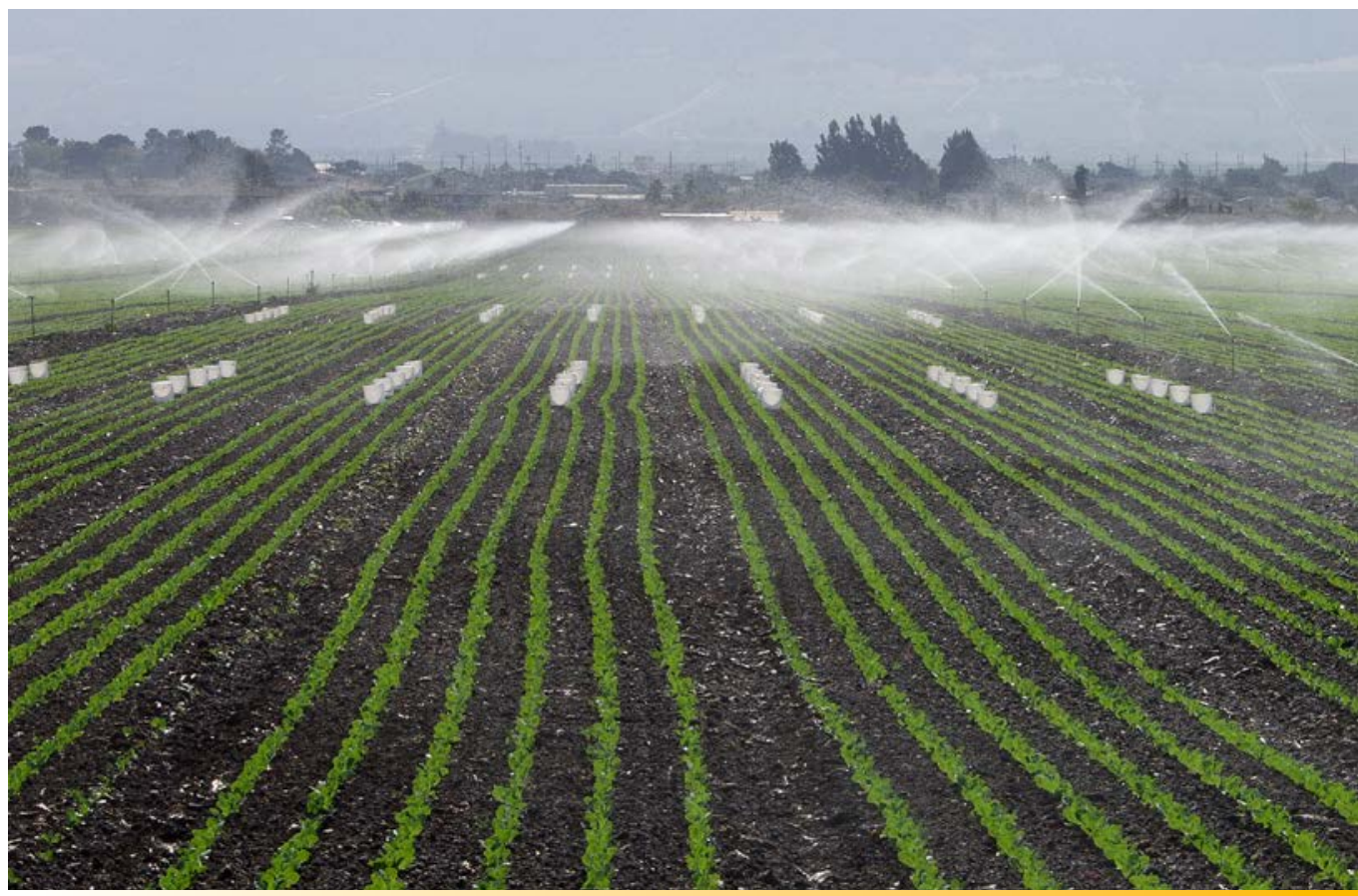

Figure 2. Grids of evenly spaced buckets set up in several locations in a field can be used to determine if a sprinkler system is applying water uniformly. Photo: M. Cahn. uniformity of drip systems, or operating sprinklers during windy conditions can also cause poor distribution uniformity.

Switching to irrigation methods that have a higher uniformity may also save water so that more acres can be irrigated under a limited water supply. As mentioned earlier, drip irrigation systems can be designed and operated to provide a DU of greater than 85 percent. Well-managed sprinkler systems can usually achieve a DU of greater than 75 percent. The uniformity of furrow and flood systems can be improved by grading land to create a uniform slope or adopting techniques such as surge irrigation, which uses intermittent water applications to reduce deep percolation losses.

\section{Accurate Irrigation Scheduling}

Irrigation efficiency can also be increased by matching the timing and amount of water with crop needs. For most vegetable crops, a

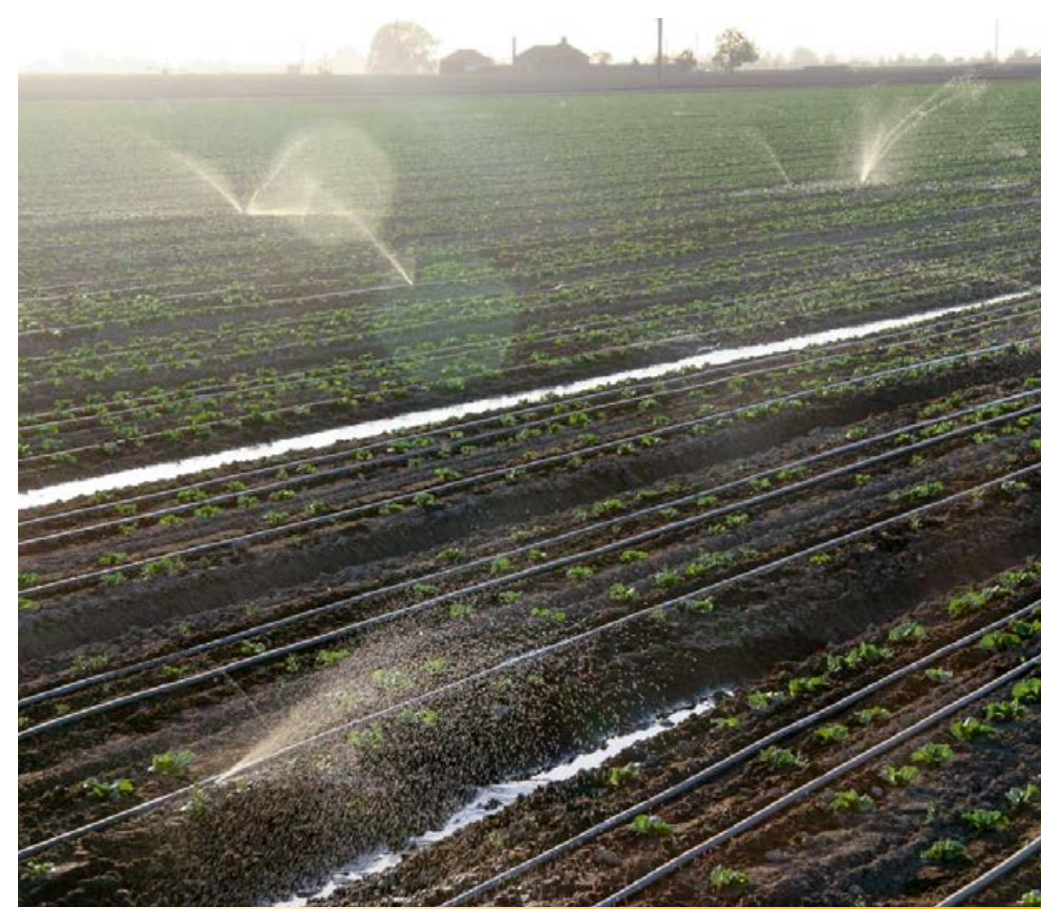

Figure 3. Regular maintenance is needed to fix leaks and head off other problems that limit the performance of an irrigation system. Photo: M. Cahn 


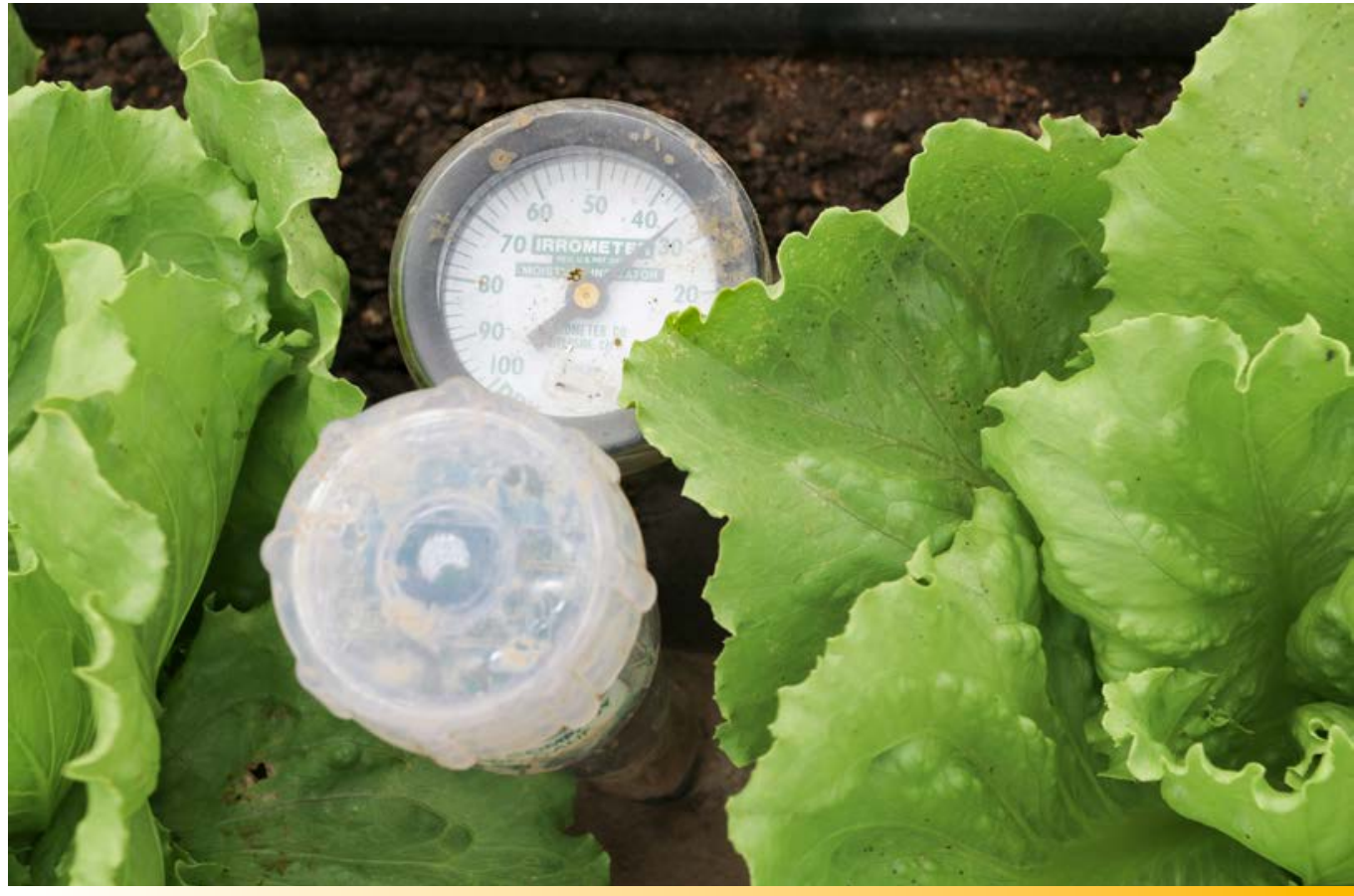

Figure 4. Monitoring soil moisture with a tensiometer can help growers decide when to irrigate. Tensiometers measure the energy that plants require to uptake water from soil. High tension values in units of kilopascals or centibars indicate dry soil conditions. Photo: M. Cahn.

combination of monitoring soil moisture and estimating crop ET provides a close approximation of crop water needs. Soil moisture monitoring (fig. 4) can provide an estimate as to when to irrigate and whether moisture is evenly distributed in a field. Crop ET provides an estimate of how much water to apply to replace crop water use. The California Irrigation Management and Information System (CIMIS) managed by the California Department of Water Resources provides daily reference ET data for most growing regions in California through their website, www.cimis.water.ca.gov. Because reference ET values correspond to well-watered grass, the data must be converted using crop coefficients to estimate crop ET. ANR publication 3396 (Scheduling Irrigations: When and How Much Water to Apply) explains how to estimate crop ET using

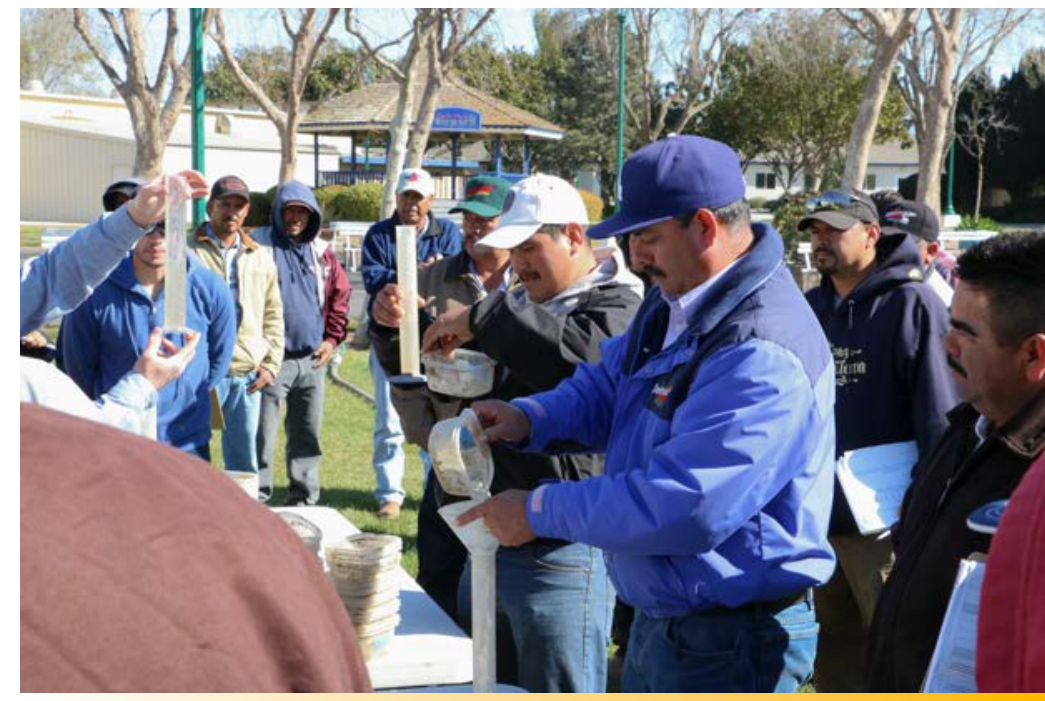

Figure 5. Training irrigators on how pressure can affect the application uniformity of a drip system and how to accurately measure pressure will improve their skills in the field. Photo: M. Cahn.

crop coefficients (B. Hanson et al. 1999). A number of online tools can assist with scheduling irrigations for vegetable crops using the CIMIS reference ET data. WaterRight (www.wateright.net), Irrigation Scheduler Mobile (weather.wsu.edu/is/), and CropManage (v3.cropmanage.ucanr.edu) are examples of online applications that can determine an irrigation schedule for vegetable crops using CIMIS reference ET data, crop coefficients, and information about the soil type and irrigation system.

Accurate irrigation scheduling requires knowledge of the application rate of the irrigation system so that one knows how long to irrigate, and it also requires keeping accurate records of when and how much water was applied. Either a flowmeter or operation time is used to estimate applied water volumes.

Precise irrigation scheduling of pressurized systems also requires consistent control of pressure so that the application rate is similar among irrigation dates. Growers should provide training to their irrigators (fig. 5) to assure that they know how to evaluate 
and adjust irrigation system pressure. Also, pressure gauges (fig. 6) should be calibrated or checked for calibration. Because most drip systems operate under low pressures, inaccuracies in operating

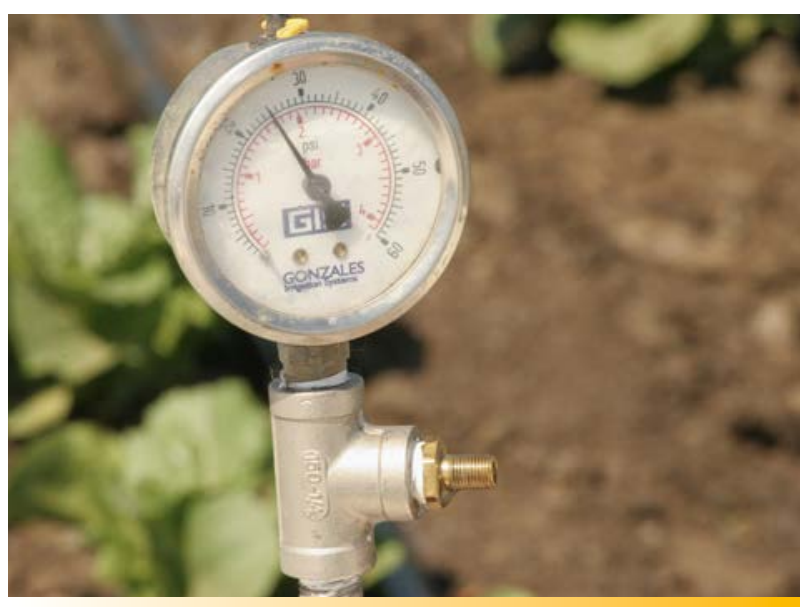

Figure 6. Monitoring pressure assures that irrigation systems are operating optimally. Photo: M. Cahn.

pressure of 2 to 3 psi can affect the application rate by 10 to 20 percent.

\section{Use an Appropriate Leaching} Fraction

Applying extra water beyond crop ET requirements can help root zone of a crop, which helps maximize production. However, using an appropriate leaching fraction for the crop type, soil salinity, and water salinity can reduce the risk of overirrigating. ANR Publication 8550 (Drought prevent salts from building in the Tip: Managing Salts by Leaching) covers how to estimate leaching requirements of crops. In cases where the quality of the water is good, minimal leaching may be required. For example, only small leaching fractions $(<5 \%)$ are required for most moderately saltsensitive crops irrigated with water of salinity levels less than 0.5 $\mathrm{dS} / \mathrm{m}$. Also, periodic monitoring of soil salinity can help determine if leaching is needed. Water applied for preirrigation and crop establishment may be sufficient to leach salts that accumulated in the soil from the previous crop. Maximizing rainfall infiltration will also minimize extra water needed for salt management during the production season.

\section{Reduce Evaporation and Transpiration Losses}

Evaporation losses in vegetable production fields can be reduced through a number of strategies. Changing irrigation methods, such as from sprinkler or furrow to drip, can minimize early season ET losses by wetting less surface area of the field. Subsurface drip will tend to have less evaporation losses than surface-placed drip tape because less water reaches the soil surface. When using sprinklers, irrigating less frequently in the early stages of the crop may reduce evaporative losses. Also irrigating at night or in the early morning can minimize evaporation water losses to the air.

Plastic mulches used in combination with drip is a common method to reduce early season evaporation losses in some vegetable crops and reduce weeds on the bed top. Minimum tillage methods that maintain cover crop residue on bed tops or furrows can also reduce evaporative losses. Cultivating weeds from furrows and bed tops will reduce losses of soil moisture. However, tilling exposes moist soil to the air and temporarily increases evaporation losses.

While there are a number of strategies to reduce evaporation losses, there are fewer options to reduce transpiration losses. Reducing plant population can lessen water use in the early stages of the crop, but it is not advisable if the lower population may reduce yield. Once the crop canopy reaches more than 70 percent coverage of the ground, savings in ET will be negligible. Misting the crop using sprinklers can lower ET by increasing humidity and lowering air temperature, but any ET savings is offset by the water lost by evaporation. Misting with water with a substantial concentration of salts risks causing salt accumulation and damage on crop leaves.

Macrotunnels can reduce both evaporation and transpiration losses by blocking a portion of the sunlight and increasing relative humidity inside the tunnels. Crop cover fabrics that are used to protect vegetables from insect pests can also reduce ET losses by shading leaves.

Chemicals applied to crops to reduce transpiration are called antitranspirants. They either cause partial closure, block stomata, or reflect sunlight that provides energy for transpiration. Kaolinite materials sprayed onto crop leaves reflect sunlight and can reduce transpiration losses but also, depending on the timing, may reduce photosynthesis and yield. In practice, these products have rarely been shown to reduce water use. 


\section{Take Advantage of Winter Rainfall Infiltration}

Enhancing winter rainfall infiltration is an effective strategy for leaching accumulated salts at the soil surface, and it can provide stored moisture that lessens the amount of water needed for preirrigating before planting. Unplanted fields should be managed to maximize infiltration of rainfall during the winter. Adding organic amendments such as compost and using minimal tillage practices can improve macropore structure and increase rainfall infiltration. Deep tillage to break up compacted layers may also improve infiltration. Fields maintained flat during the winter, or with wide beds, will tend to have less runoff than fields with peaked listed beds. Orienting beds to minimize slope will reduce runoff more than beds oriented parallel with the slope.

Preventing crusting of the soil surface is also key to encouraging rainfall to infiltrate rather than running off. Gypsum, broadcasted onto the soil surface, can prevent soil aggregates from breaking down under the impact of rain drops that create a surface crust. Cover crops also protect the soil surface from the crusting effects of rainfall, but they must be planted and established before the first major rain event. Since cover crops use soil moisture, they may reduce soil moisture storage for the subsequent vegetable crop. Reduced-biomass cover crops are an option to protect the soil from the crusting effects of rain, and this strategy minimizes the risk of losing stored soil moisture before planting. Reducedbiomass cover crops (fig. 7) are killed with an herbicide or by mechanical means after they reach full canopy cover, usually when they have accumulated 0.5 to 0.75 tons of dry matter per acre. Evapotranspiration of the cover crop declines as it dies. UC research studies demonstrated that the decomposing residue of the cover crop was effective at increasing infiltration during winter storm events compared to a bare-fallow field.

\section{Develop and Use Alternate Water Supplies}

Growers in agricultural regions facing recurring droughts may consider developing new water supplies. In the middle of a drought, this option often involves drilling new wells or improving old wells. Another source may be surface water transfers from other regions.

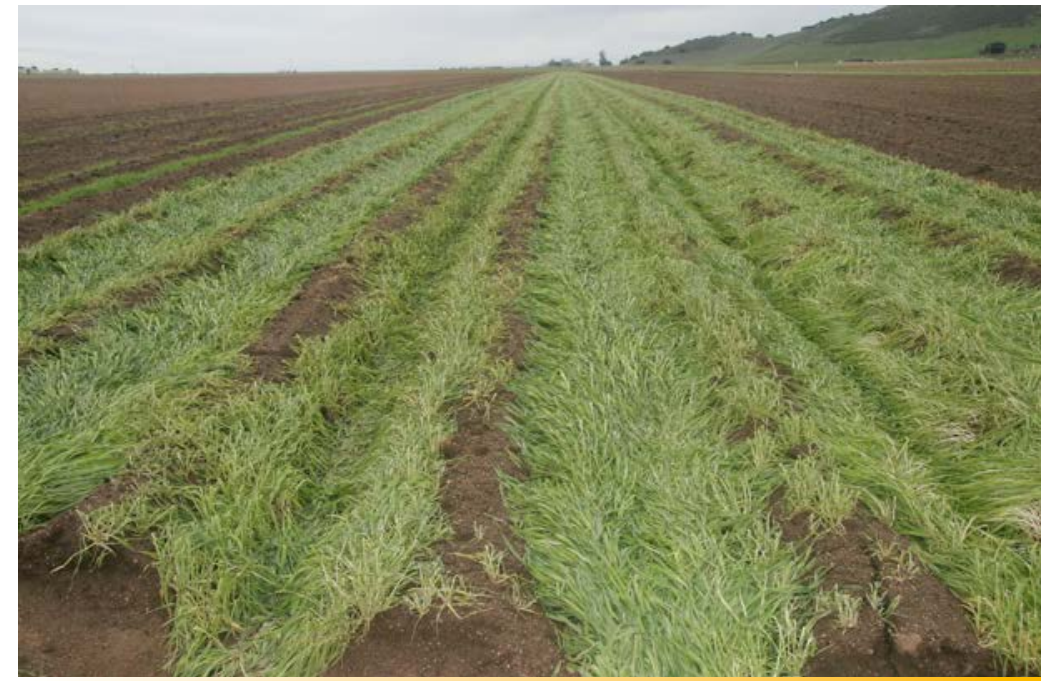

Figure 7. Low-biomass cover crops grown during the winter can increase infiltration of rainfall and reduce storm water runoff. Photo: M. Cahn.

These water supplies are often not sustainable for long-term use. Overextracting ground water can lead to land subsidence or degrade ground water quality. Overpumping near the coast has lowered ground water levels below sea level, causing saline ocean water to intrude into the aquifers.

More sustainable water development requires long-term planning. This may include building reservoirs to capture and store storm water runoff or creating projects to enhance recharge to ground water during wet years. Other opportunities may include developing recycled water for agriculture irrigation or making use of degraded water by blending with higher-quality water (refer to ANR Publication 8534, Drought Tip: Use of Treated Wastewater for Crop Production). Using water of higher salinity is also an option that can be considered for vegetables that are salt tolerant, such as broccoli (refer to ANR Publication 8558, Drought Tip: Water Quality Guidelines for Vegetable and Row Crops), or it can be used at a later stage of maturity when the crop may be less sensitive to salinity. Reusing irrigation tail water is an option, but food safety concerns of produce buyers and shippers need to be addressed. Monitoring 
for potentially human pathogenic bacteria such as E. coli or Salmonella in the water may be required, as well as a chlorination or other method of assuring that the water is safe.

\section{Summary}

The major strategies for using a limited supply of water to profitably grow vegetables include the following:

- maximizing production and profitability by selecting the best land, using the most productive varieties, and applying good fertility and pest management practices

- optimizing irrigation system design, operation, maintenance, and scheduling so that a limited water supply can be spread over the maximum acres and still meet crop needs

- infiltrating winter rainfall

- developing new or alternative water supplies

Often the amount of water used for preseason and establishment can be reduced if soil moisture is carefully monitored. Using irrigation methods that are efficient, such as drip, can often reduce water lost by surface runoff, evaporation, and deep percolation. Scheduling irrigations to match crop needs by following the crop ET demand can avoid periods of over and underapplication, thereby helping to maximize yield and quality. Strategies such as using antitranspirants to reduce crop ET or reducing plant populations are not recommended because they are reducing yield, and the amount of water saved is often minimal.

\section{References}

Austin, J. T. 2012. Floods and droughts in the Tulare Lake Basin. Sequoia Natural History Association.

Cahn, M. 2019. Drought tip: Drought planning for vegetable production. Oakland: University of California Agriculture and Natural Resources Publication 8632. UC ANR Catalog website, https://anrcatalog.ucanr.edu/pdf/8632.pdf.

Grismer, M. 2017. Drought tip: Use of treated wastewater for crop production. Oakland: University of California Agriculture and Natural Resources Publication 8534. UC ANR catalog website, http://anrcatalog.ucanr.edu/pdf/8534.pdf.

Grattan, S. R. 2016. Drought tip: Water quality guidelines for vegetable and row crops. Oakland: University of California Agriculture and Natural Resources Publication 8558. UC ANR catalog website, http://anrcatalog.ucanr.edu/pdf/8558.pdf.

Cahn, M., and K. Bali. 2016. Drought tip: Managing salts by leaching. Oakland: University of California Agriculture and Natural Resources Publication 8550. UC ANR catalog website, http://anrcatalog.ucanr.edu/pdf/8550.pdf.

Hanson, B., L. Schwankl, and A. Fulton. 1999. Scheduling irrigations: When and how much water to apply. Oakland: University of California Agriculture and Natural Resources Publication 3396.

Lascano, R. J., and R. E. Sojka. 2007. Irrigation of agricultural crops. Madison, WI: American Society of Agriculture. 


\section{For More Information}

To order or obtain ANR publications and other products, visit the ANR Communication Services online catalog at http://anrcatalog.ucanr.edu/ or phone 1-800-994-8849. You can also place orders by mail or request a printed catalog of our products from

\section{University of California}

Agriculture and Natural Resources

Communication Services

2801 Second Street

Davis, CA 95618

Telephone 1-800-994-8849

E-mail: anrcatalog@ucanr.edu

(02019 The Regents of the University of California. This work is licensed under the Creative Commons Attribution-NonCommercial-NoDerivatives 4.0 International License. To view copy of this license, visit http://creativecommons.org/licenses/by-nc-nd/4.0/ or send a letter to Creative Commons, PO Box 1866, Mountain View, CA 94042, USA.

Publication 8635

ISBN-13: 978-1-62711-079-2
The University of California, Division of Agriculture and Natural Resources (UC ANR) prohibits discrimination against or harassment of any person in any of its programs or activities on the basis of race, color, national origin, religion, sex, gender, gender expression, gender identity, pregnancy (which includes pregnancy, childbirth, and medical conditions related to pregnancy or childbirth), physical or mental disability, medical condition (cancerrelated or genetic characteristics), genetic information (including family medical history), ancestry, marital status, age, sexual orientation, citizenship, status as a protected veteran or service in the uniformed services (as defined by the Uniformed Services Employment and Reemployment Rights Act of 1994 [USERRA]), as well as state military and naval service.

UC ANR policy prohibits retaliation against any employee or person in any of its programs or activities for bringing a complaint of discrimination or harassment. UC ANR policy also prohibits retaliation against a person who assists someone with a complaint of discrimination or harassment, or participates in any manner in an investigation or resolution of a complaint of discrimination or harassment. Retaliation includes threats, intimidation, reprisals, and/or adverse actions related to any of its programs or activities.

UC ANR is an Equal Opportunity/Affirmative Action Employer. All qualified applicants will receive consideration for employment and/or participation in any of its programs or activities without regard to race, color, religion, sex, national origin, disability, age or protected veteran status.

University policy is intended to be consistent with the provisions of applicable State and Federal laws.

Inquiries regarding the University's equal employment opportunity policies may be directed to: Affirmative Action Contact and Title IX Officer, University of California, Agriculture and Natural Resources, 2801 Second Street, Davis, CA 95618, (530) 750-1397. Email: titleixdiscrimination@ucanr.edu. Website: http://ucanr.edu/sites/anrstaff/Diversity/Affirmative_ Action/.

To simplify information, trade names of products have been used. No endorsement of named or illustrated products is intended, nor is criticism implied of similar products that are not mentioned or illustrated.

An electronic copy of this publication can be found at the ANR Communication Services catalog website, http://anrcatalog.ucanr.edu/.

UC This publication has been anonymously peer reviewed for technical accuracy by University of California scientists and other qualified professionals. This review process was managed by ANR Associate Editor for Vegetable Crops Scott Stoddard.

web-3/19-LR/WS 